\title{
BREEDING RANGE EXTENSION OF THE LARK SPARROW INTO WEST- CENTRAL MANITOBA
}

WILLIAM J. WALLEY, 19 Edgar Avenue, Dauphin, Manitoba. R7N 0R4

In Manitoba the Lark Sparrow is known to breed in the southern portion of the province to about $50^{\circ} \mathrm{N}$ latitude. Breeding records have been reported for Oak Lake, Treesbank and Winnipeg ${ }^{3}$ and more recently for the Carberry-Shilo area (Table 1).

From 1971 to 1984 Lark Sparrow sightings and nestings were recorded north of their previously known breeding range, by the author and other naturalists at Birtle, Dauphin and in Riding Mountain National Park. The breeding records extend the formerly known breeding range of the species approximately $125 \mathrm{~km}$ north in the province (Fig. 1).

\section{Early Spring and Other Sight Records}

According to Baepler early dates of spring arrival for Manitoba are 28 April at Margaret and 6 May at Treesbank; the average date at

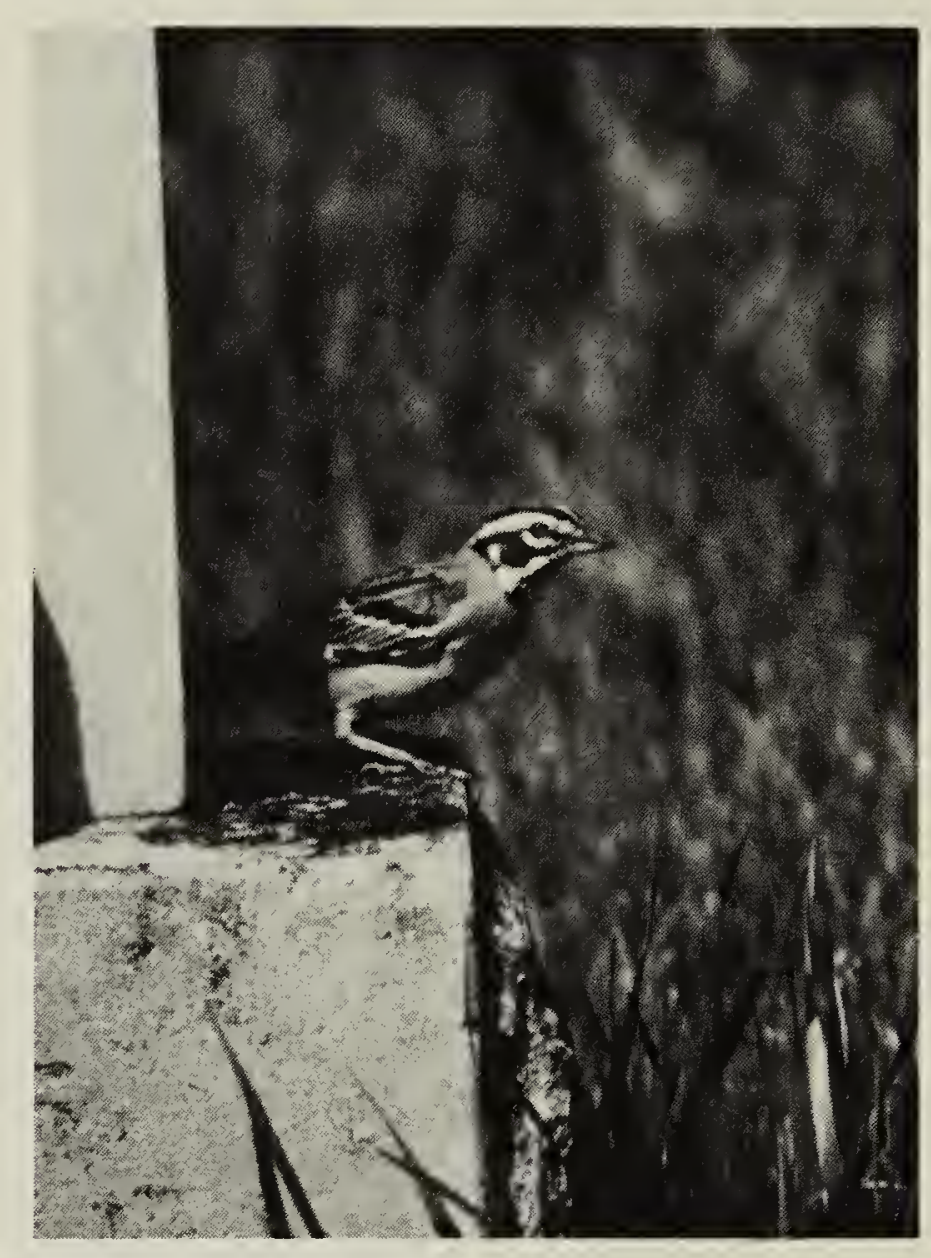

Lark Sparrow

W.J. Walley

Table 1. ADDITIONAL NESTING RECORDS OF THE LARK SPARROW IN ITS PREVIOUSLY KNOWN BREEDING RANGE IN MANITOBA

\begin{tabular}{|c|c|c|c|}
\hline Year & Location & Dates: Eggs/Young & Observer \\
\hline 1966 & near Shilo & $\begin{array}{c}2 \text { July - } 3 \text { eggs } \\
7 \text { July - } 2 \text { infertile eggs } \\
\text { plus } 1 \text { young } \\
14 \text { July - } 1 \text { young } \\
15 \text { July - Nest empty }\end{array}$ & $\begin{array}{l}\text { John Lane and the } \\
\text { Junior Birderst }\end{array}$ \\
\hline 1969 & near Carberry & 22 June -1 egg, plus 2 young & Norman Cleveland + \\
\hline 1980 & $\begin{array}{l}13 \mathrm{~km} \mathrm{~W} \text { of } \\
\text { Carberry }\end{array}$ & 21 June - 4 young & Mamie McCowant \\
\hline
\end{tabular}

+Prairie Nest Records Scheme. Manitoba Museum of Man and Nature, Winnipeg. 
Treesbank over a 19-year period was 14 May $^{1}$ (as documented by the Criddles). Cleveland et al report that the Lark Sparrow is rarely sighted in the last half of April in southeastern Manitoba. More recent spring arrival dates for the area north of Riding Mountain National Park include the following: one adult in the Dauphin cemetery 19 April 1981 and at least one there 30 April 1978 (W.L. Clark, pers. comm.). The following day, 1

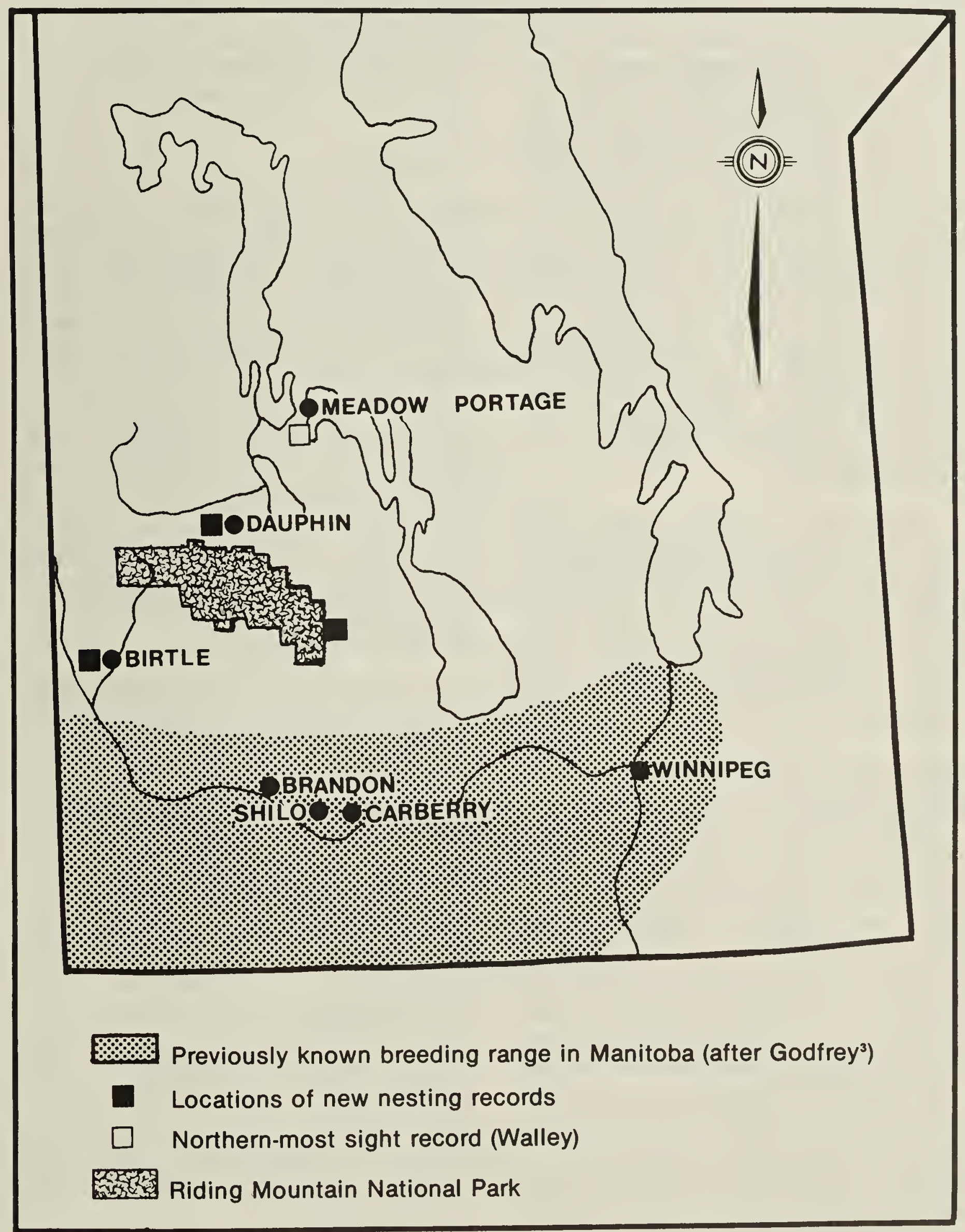

Figure 1. New breeding and sight records of the Lark Sparrow in west-central Manitoba. 
May, I observed a Lark Sparrow in the cemetery. My most northerly sighting was of at least three Lark Sparrows in migration 19 May 1974 just south of the village of Meadow Portage $\left(51^{\circ}\right.$ $40^{\prime} \mathrm{N}$ and $99^{\circ} 50^{\prime} \mathrm{W}$ ) between lakes Winnipegosis and Manitoba. The birds were associating with Whitethroated, White-crowned and Harris' Sparrows during a rain. This observation was at the same latitude as Lake St. Martin which is the northern limit of the species' known occurrence in Manitoba. ${ }^{3}$ My late fall record was a single bird on swathed grain south of Dauphin on 22 August 1971 (also my first record). The late date of fall departure reported from Manitoba is 11 September at Treesbank. ${ }^{1}$ In eastern Manitoba the species is uncommon to about 10 August, but there is one out-of-season record in mid-September. ${ }^{2}$

Additional records, other than nesting, include sightings at Birtle in the summers of 1975 and 1976 (Edgar Dandrigde, pers. comm.) and single bird sightings 21 May 1979 in Vermillion Park, Dauphin and 18 May 1981 at the north end of Lake Dauphin.

\section{Breeding Records, Habitat and Nest Site Selection}

On 6 June 1971 Park Warden R.T. Dowhan found a Lark Sparrow nest with 3 eggs $0.3 \mathrm{~km}$ west of the east gate near Highway 19 in Riding Mountain National Park (Prairie Nest Records Scheme). On 16 June the nest still contained 3 eggs, but was empty on 19 June. The nesting had occurred in a horse pasture with a few browsed and stunted shrubs surrounded by elm, oak, maple, ash and aspen forest. The nest was located in sparse grass on broken shale substrate with a $60 \mathrm{~cm}$, 3-stemmed sapling White Birch nearby.

Edgar Dandridge found a nest with
3 eggs at Birtle $\left(50^{\circ} 25^{\prime} \mathrm{N}, 101^{\circ} 10^{\prime} \mathrm{W}\right)$ on 28 June, 1974. At the top of a ravine opening on the north crest of the Birdtail Valley, the nest was in sparse snowberry on a well grazed pasture adjacent to a stand of Bur Oak. Dandridge had observed a Lark Sparrow feeding two young and a cowbird, all capable of flight, in the same area the previous summer, 1973.

In late spring 1973 Joan Wells reported that Lark Sparrows had successfully nested at the southwest edge of Dauphin $\left(51^{\circ} 05^{\prime} \mathrm{N}, 100^{\circ} 05^{\prime} \mathrm{W}\right.$ ) (pers. comm.). The birds built their nest among potato plants of a market garden only a few meters from hardwood deciduous forest along the Vermillion River. Nesting attempts in the same area in 1975 failed (Wells, pers. comm.). On 18 May the sparrows were seen building a nest between two furrows on a black field with no vegetation in the vicinity! On 26 May the nest contained two eggs and several small chunks of black soil obviously abandoned.

In the spring of 1977 efforts were made to determine the breeding status of Lark Sparrow at Dauphin. At the Dauphin cemetery, $0.5 \mathrm{~km}$ south of where Wells had made observations, four nests were located. In addition to tomb-stones, there were scattered hardwood trees with a solid hardwood forest adjacent to the west side of the cemetery. One nest was found in the cemetery in 1979. Another locality in the Dauphin area where Lark Sparrows have been found nesting has been at the Carmichael farm about $13 \mathrm{~km}$ southsoutheast of Dauphin (just north of Riding Mountain National Park) where nests were successful in 1983 and 1984 (Table 2).

At Carmichael's on 18 June 1984 Lark Sparrows were found in the 
Table 2. BREEDING EVIDENCE OF THE LARK SPARROW NORTH OF ITS PREVIOUSLY KNOWN RANGE IN MANITOBA

\begin{tabular}{|c|c|c|c|c|}
\hline Year & Location & Dates: Eggs/Young & Success * & Observer \\
\hline 1971 & $\begin{array}{l}\text { east gate, Riding } \\
\text { Mt. National Park } \\
\text { (Hwy. 19) }\end{array}$ & $\begin{array}{l}6 \text { June - } 3 \text { eggs } \\
16 \text { June - } 3 \text { eggs } \\
19 \text { June - nest empty }\end{array}$ & failed & Dowhan $^{a}$ \\
\hline 1973 & $\begin{array}{l}\text { southwest edge } \\
\text { of Dauphin }\end{array}$ & 3 young fledged & successful & Wells \\
\hline 1973 & Birtle & $\begin{array}{l}2 \text { young and a cowbird } \\
\text { being fed by an adult }\end{array}$ & successful & Dandridge \\
\hline 1974 & Birtle & 28 June - 3 eggs & failed & Dandridge \\
\hline 1975 & $\begin{array}{l}\text { southwest edge } \\
\text { of Dauphin }\end{array}$ & $\begin{array}{l}18 \text { May - nest building } \\
26 \text { May - } 2 \text { eggs } \\
\text { (abandoned) }\end{array}$ & failed & Wells \\
\hline 1975 & $\begin{array}{l}\text { southwest edge } \\
\text { of Dauphin }\end{array}$ & $\begin{array}{l}\text { second nesting attempt } \\
\text { of the } 26 \text { May pair } \\
\text { (above) }\end{array}$ & failed & Wells \\
\hline 1977 & $\begin{array}{l}\text { Dauphin } \\
\text { Cemetery }\end{array}$ & $\begin{array}{l}21 \text { May - } 4 \text { eggs } \\
24 \text { May - } 4 \text { eggs } \\
7 \text { June - young fledged } \\
\text { (feather scales) }\end{array}$ & successful & Walley \\
\hline 1977 & $\begin{array}{l}\text { Dauphin } \\
\text { Cemetery }\end{array}$ & $\begin{array}{l}21 \text { May - female on nest } \\
25 \text { May - } 3 \text { young, } 2-3 \\
\text { days old } \\
26 \text { May - nest empty }\end{array}$ & failed & Walley \\
\hline 1977 & $\begin{array}{l}\text { Dauphin } \\
\text { Cemetery }\end{array}$ & $\begin{array}{l}26 \text { May - } 3 \text { eggs } \\
28 \text { May - parasitized by } \\
\text { Brown-headed Cowbird } \\
\text { and deserted }\end{array}$ & failed & Walley \\
\hline 1977 & $\begin{array}{l}\text { Dauphin } \\
\text { Cemetery }\end{array}$ & $\begin{array}{l}7 \text { June }-4 \text { eggs } \\
18 \text { June }-3 \text { young } \\
29 \text { June - nest empty } \\
\text { feather scales }\end{array}$ & successful & Walley \\
\hline 1979 & $\begin{array}{l}\text { Dauphin } \\
\text { Cemetery }\end{array}$ & $\begin{array}{l}21 \text { May - building nest } \\
28 \text { May - } 3 \text { eggs plus } \\
\text { four cowbird eggs } \\
\text { (abandoned) }\end{array}$ & failed & Walley \\
\hline 1983 & $\begin{array}{l}\text { Dauphin } \\
\text { Cemetery }\end{array}$ & $\begin{array}{l}\text { About } 1 \text { July - } 4 \text { young } \\
\text { fledged }\end{array}$ & successful & $\begin{array}{l}\text { Grounds- } \\
\text { keepers }\end{array}$ \\
\hline 198 & $\begin{array}{l}\text { Carmichael Farm } \\
13 \mathrm{~km} \text { sse of } \\
\text { Dauphin }\end{array}$ & $\begin{array}{l}13 \text { July - } 3 \text { eggs } \\
16 \text { July - } 3 \text { eggs } \\
20 \text { July - } 3 \text { young about } 2 \\
\text { days old } \\
23 \text { July - } 3 \text { young } \\
27 \text { July - young gone - } \\
\text { feather scales }\end{array}$ & successful & Walley \\
\hline
\end{tabular}

March 1985. 43(1) 
Table 2. BREEDING EVIDENCE OF THE LARK SPARROW NORTH OF ITS PREVIOUSLY KNOWN RANGE IN MANITOBA (continued)

\begin{tabular}{|c|c|c|c|c|}
\hline Year & Location & Dates: Eggs/Young & Success* & Observer \\
\hline 1984 & Carmichael Farm & $\begin{array}{l}18 \text { June - adults carrying } \\
\text { food to fledged young } \\
\text { perched in nearby trees }\end{array}$ & successful & Walley \\
\hline 1984 & Carmichael Farm & $\begin{array}{l}30 \text { June - } 4 \text { eggs } \\
10 \text { July - nest empty }\end{array}$ & failed & Walley \\
\hline
\end{tabular}

same area where they had nested the previous summer. Alarmed, foodcarrying adults were seen with immatures perched in nearby trees. In the same area on 30 June a wellconcealed nest with four eggs was discovered in a small patch of coneflower (Rudbeckia laciniata) in early growth form.

The habitat was well-drained, wellgrazed pasture with many small clumps of short, broad-leaved plants, notably the Early Coneflower. The Lark Sparrows nested where a few American Elm, Green Ash and Bur Oak were scattered near aspen forest with a few maples and ash which formed the south boundary of the pasture.

In New Mexico and Oklahoma Lark Sparrows build nests in shrubs and trees as well as on the ground. One nest was located $7.5 \mathrm{~m}$ above the ground.' As in Wyoming, all nests reported in this study were on the ground. ' Lark Sparrows have a mark. ed tendency to nest in shade, such as that provided by a tuft of grass or broad-leaved plants. At the Dauphin cemetery in 1977 mowers did not pass between the closely-spaced tombstones in one area; a narrow strip of uncut grass grew between the south end of one tombstone and the north end of the next. The four nests found that year were abutted against the north sides of the concrete bases of the tombstones where maximum shade could be obtained (Fig. 2). In the cold, late spring of 1979 grass was very short. Lark Sparrows built a nest in another area of the cemetery on the west side of a flat headstone which was almost flush with the ground. On 28 May a nest being built on 21 May was found to be immediately beneath the green plastic leaves of an artificial flower! The selection of this nest site, while shunning the superior shade of the tombstones used by the 1977 pairs, suggests that the birds had chosen a site which provided a measure of both shade and cover from predators.

\section{Colonial Nesting}

Lark Sparrows are reputed to be highly pugnacious during the establishment of territory, but paradoxically, nest in loose colonies with aggressiveness towards other members of the species and other birds declining markedly after incubation begins.' At the Dauphin cemetery 21 May, 1979, two Lark Sparrows were observed quietly perched less than a metre apart on a limb of Bur Oak with a Chipping Sparrow perched between them! A third Lark Sparrow stood on a nearby road. No aggression between any of the birds was noted. The nesting stage of these birds was unknown although 


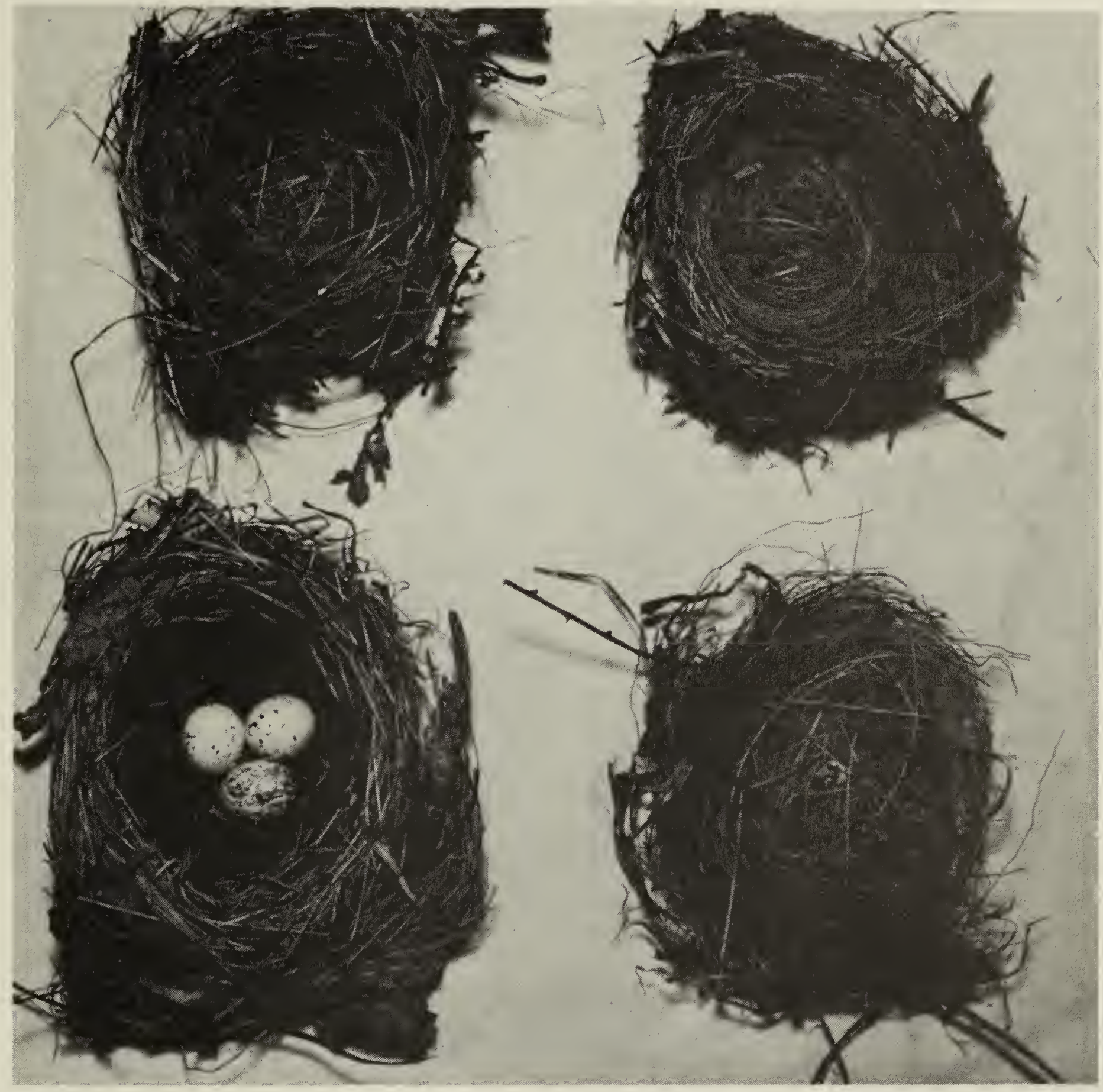

Figure 2. Lark Sparrow nests found in Dauphin cemetery in 1977. Note the single straight side of each nest where it abutted against a tombstone.

it was the same day that the pair was found building their nest under an artificial plant some distance away. Incubation had not begun in this nest, but the social disposition of this pair towards other birds was unknown. Of the four nests found in the cemetery in 1977 , three would fit within a $50 \mathrm{~m}$ radius circle with the fourth nest only about $80 \mathrm{~m}$ away. In Oklahoma seven nests were found even closer together.'

\section{Nest Parasitism}

Baepler discovered that if nests were parasitized by Brown-headed Cowbirds early in incubation nest desertion occurred. ' However he obtained evidence suggesting that cowbird eggs would be tolerated if laid in the late stages of incubation or later in the season after the birds had experienced one or more nesting failures. Of the nestings reported in Table 2, both nests with cowbird 
eggs - one in 1977 and one in 1979 - were abandoned with none of the the cowbird or sparrow eggs showing any discernible embryo development. Interestingly, the 1973 observation by Dandridge at Birtle involved a Lark Sparrow feeding two sparrow young and one cowbird (pers. comm.). Unfortunately the date of this sighting was not recorded.

\section{Broods}

Lark Sparrows raise only one brood near the northern fringe of their geographical range, whereas at least two broods are raised farther south. ${ }^{1}$ It is tempting to speculate that two broods may have been raised at the Carmichael farm at Dauphin in 1984. On 18 June adults were seen carrying food and giving alarm notes as fledged immatures perched in nearby trees. At the same site a nest with four eggs was found on 30 June. This nest had failed when checked 10 July. Thus no information was obtained as to when the eggs in the 30 June nest had been laid. Nests with young have been found at Dauphin as early as 25 May (1977), in mid-June and as late as 23 July (1983). It seems that the species could raise two broods in one season in this area. However the late nesting 30 June could have been a second attempt by a different pair of birds, as could have been the case with the 13-23 July 1983 nesting (Table 2).

\section{Acknowledgements}

I wish to thank Herbert W.R. Copland, Manitoba Museum of Man and Nature, for furnishing copies of Lark Sparrow nest records from the Prairie Nest Records Scheme. Robert MacKenzie of the Manitoba Dept. of Natural Resources provided the base map. Edgar Dandridge and Joan Wells provided information on nests at Birtle and Dauphin, respectively.

'BAEPLER, D.H. 1968. In: Bent, A.C. 1968. Life histories of North American cardinals, grosbeaks, buntings, towhees, finches, sparrows, and allies. Part Two. Dover Publications, New York.

${ }^{2}$ CLEVELAND, N.J., C.W. CUTHBERT, G.D. GRIEEF, G.E. HOLLAND, P.A. HORCH, R.W. KNAPTON, R.F. KOES, N.F. MURDOCH, W.P. NEILY and I.A. WARD. 1980. Birder's guide to southeastern Manitoba. Eco Series No. 1. Manitoba Naturalists Society, Winnipeg. 58 pp.

${ }^{3}$ GODFREY, W.E. 1966. The birds of Canada. Natl. Mus. Can. Bull. 203. Ottawa. $428 \mathrm{pp}$.

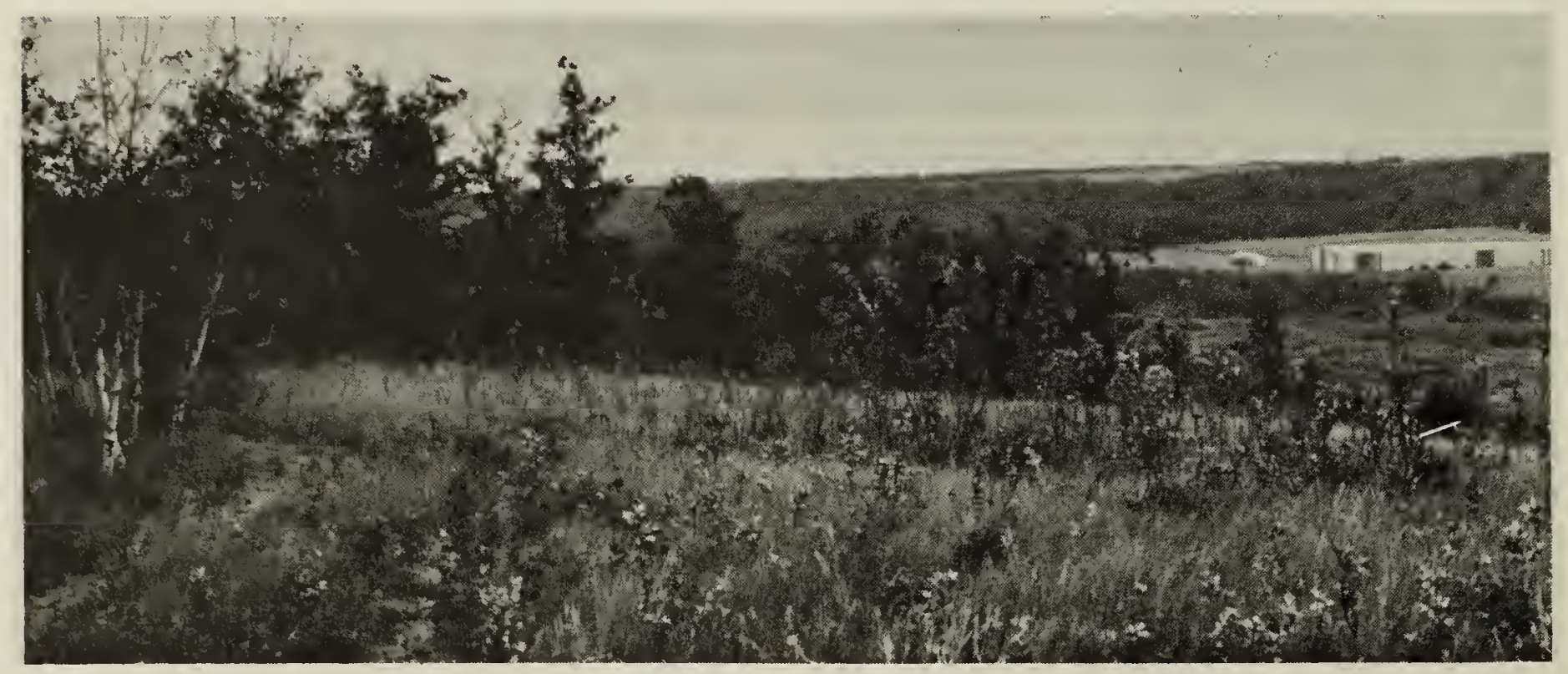

Nesting habitat of Lark Sparrows on north crest of the Birdtail Valley at Birtle

W.J. Walley 